\title{
Morphotectonics and incision of the Kaoping submarine canyon, SW Taiwan orogenic wedge
}

\author{
Cheng-Shing Chiang ${ }^{\mathrm{a}, *}$, Ho-Shing $\mathrm{Yu}^{\mathrm{b}}$ \\ ${ }^{a}$ Hsiuping Institute of Technology, No. 11, Gungye Road, Dali City, Taichung, Taiwan, Republic of China \\ ${ }^{\mathrm{b}}$ Institute of Oceanography, National Taiwan University, Taipei, Taiwan, Republic of China
}

Received 7 September 2005; received in revised form 15 February 2006; accepted 15 February 2006

Available online 24 March 2006

\begin{abstract}
The Kaoping submarine canyon developed on the frontal orogenic wedge off SW Taiwan and is the largest one among others. The canyon begins at the mouth of the Kaoping River, crosses the narrow shelf and broad slope region, and finally merges into the northern Manila Trench for a distance of about $260 \mathrm{~km}$. Using reflection seismic sections and bathymetric mapping this paper reveals the geomorphic characteristics of the Kaoping Canyon strongly related to structural and sedimentary processes. The combined morphometry statistics analysis, seismic interpretations of structures and examinations of detailed bathymetric charts indicate that regional canyon morphology is strongly linked to intrusions of mud diapirs in the upper reach of the canyon and thrust faulting in the middle and lower reaches which produce two prominent morphological breaks of the course of the Kaoping Canyon with two sharp bends. Although excavation of floor and enlargement of the Kaoping Canyon are mainly attributed to downslope erosion of seabed, incision of this canyon is also strongly complicated by mud diapiric intrusions (upper reach), westward thrust faults (middle reach), and regional base level tilting (lower reach). The resultant cross-sectional morphology along the Kaoping Canyon changes considerably, ranging from U-shaped, broad V-shaped, to irregular troughs. The Kaoping Canyon may be served as a variant of canyon model of active margins with a distinct morphology of two sharp bends along the canyon course associated with structure deformation.
\end{abstract}

(C) 2006 Elsevier B.V. All rights reserved.

Keywords: Morphotectonics; Morphology; Incision; Submarine canyon; Taiwan

\section{Introduction}

\subsection{Geological settings}

The island of Taiwan is located at the juncture of the Ryukyu and Luzon Arcs along the western boundary of the Philippine Sea plate (Fig. 1). The fold-and-thrust belt of Taiwan was formed by an oblique collision between

\footnotetext{
* Corresponding author. Fax: +886 424961187.

E-mail address: wind@mail.hit.edu.tw (C.-S. Chiang).
}

the Luzon Arc and the Chinese margin beginning in the Late Miocene-Early Pliocene (Suppe, 1981; Ho, 1988). The foreland region of the Chinese margin was flexed down in response to the topographic loading of the Taiwan orogen, forming an east-dipping, wedge-shaped foreland basin flanking the Taiwan orogen (Covey, 1984; Yu and Chou, 2001). The oblique arc-continent collision in Taiwan is actively propagating to the south (Suppe, 1987), and the offshore areas in southwestern Taiwan represent the modern initial collision zone (Lallemand and Tsien, 1997), forming a modern 

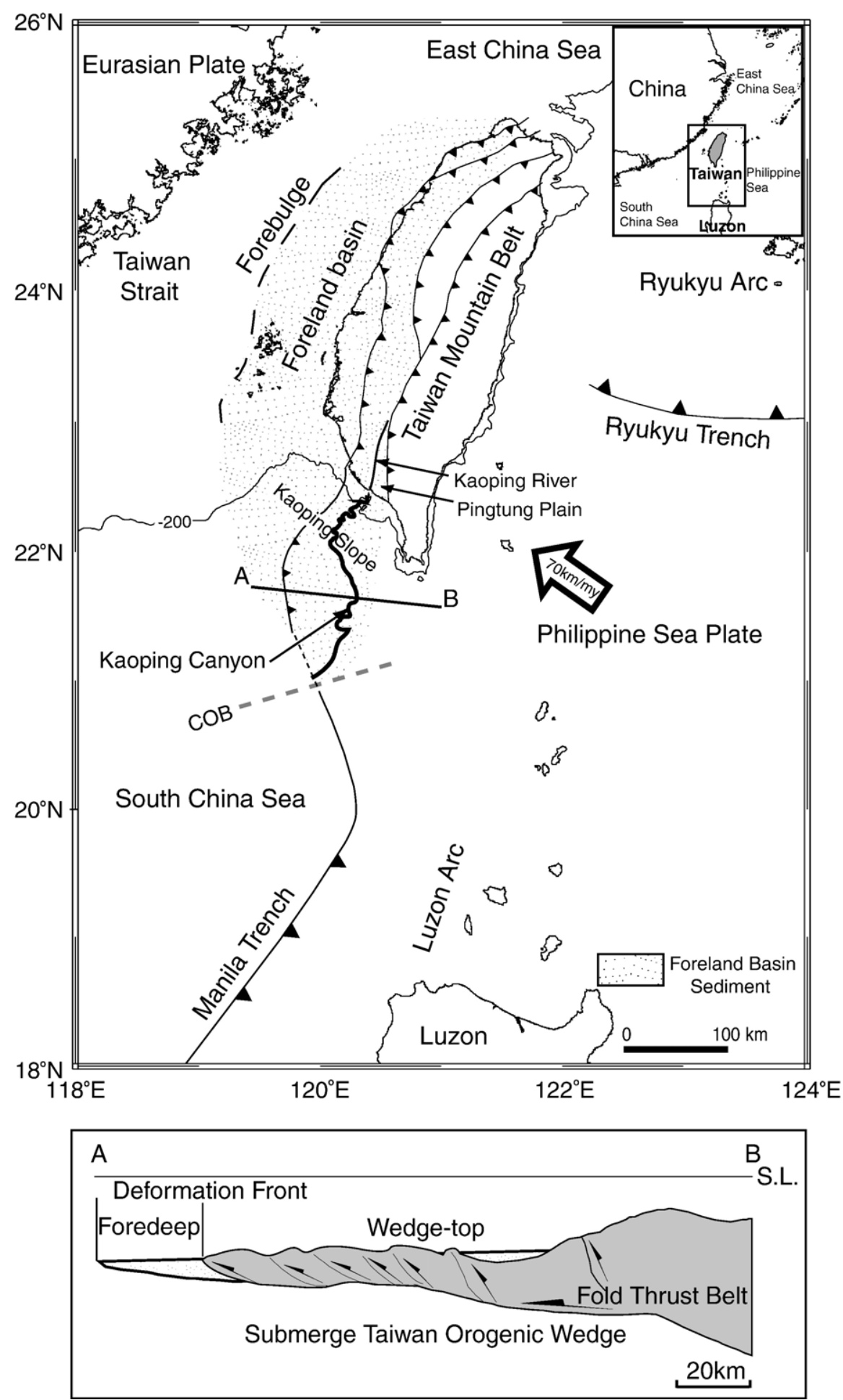

Fig. 1. Geological settings of Taiwan showing a foreland basin west of the Taiwan mountain belt. The shelf-slope region off SW Taiwan represents an early development of the western Taiwan foreland basin. COB denotes the continent-oceanic boundary. The map shows the regional plate-tectonic settings of the island of Taiwan (upper panel). The Kaoping Slope constitutes the main body of the submarine frontal orogenic wedge of southern Taiwan where sediments derived from the Taiwan orogen have accumulated upon it (lower panel). 
submarine orogenic wedge and becoming the wedge-top depozone as a part of the western Taiwan foreland basin system (Chiang et al., 2004).

In southwestern Taiwan, sediments derived from the Taiwan orogen accumulate progressively southwestward on top of the orogenic wedge to fill up the Pingtung Plain and, seaward the Kaoping Shelf and Kaoping Slope (Fig. 1). The Pingtung Plain lies west of the Taiwan mountain belt and is filled with more than 5000-m thick PlioPleistocene sediments derived from the Taiwan orogen (Hsieh, 1970). Seaward of the Pingtung Plain lies the Kaoping Shelf, a very narrow (10-km wide) and shallow (40-m deep) island shelf ( $\mathrm{Yu}$ and Chiang, 1997). Sediments have progressively deposited seaward beyond the Pingtung Plain to form the Kaoping Shelf where sediments easily escaped this narrow shelf to the deep basin (Milliman and Syvitski, 1992). Farther seaward of the Kaoping Shelf, the Kaoping Slope is a broad and deeply sloping region, extending SW to a water depth of $3500 \mathrm{~m}$, and merging into the northern Manila Trench of the South China Sea (Fig. 1). The Kaoping Slope is divided into the upper and the lower slopes by linear prominent escarpments in water depths ranging from 1200 to $2000 \mathrm{~m}$ with more than $800 \mathrm{~m}$ of relief (Figs. 2 and 3). The Kaoping Slope is characterized by irregular topography closely related to deformations of folding, faulting and mass wasting processes. Westvergent folds and thrust faults are the dominant structural features in the lower slope (Reed et al., 1992; Liu et al., 1997; Chiang et al., 2004). Widespread mud diapiric intrusions in the shelf and upper slope region have been recognized (e.g., Chang, 1993; Sun and Liu, 1993; Yu and Lu, 1995; Chow et al., 2001). The detailed descriptions of morphology of mud dispiric intrusions and related structures were given. However, the mechanisms of mud diapirism in the shelf and slope region off SW Taiwan were little discussed. In fact, the origin of mud diapirs still remains controversial. For instance, mud diapirism may be due to expulsion of fluids (Westbrook and Smith, 1983), sediment overburden (Limonov et al., 1996), regional plate motion (Sumner and Westbrook, 1977), rapid sedimentation and subsequent tectonic compression (Aisan et al., 2001) and compressional tectonic activity (Yassir, 2003). The discussion of exact mechanism of mud diapirism is beyond the scope of this paper. Hence, in the paper we concentrate on interpretations of intrusions of mud diapirs from seismic characteristics using seismic reflection profiles. The mud diapir is imaged as a zone of chaotic reflections that disrupt the surrounding sedimentary layers from the top of the mud source layer upwards, up to the seabed higher in the section.

\subsection{Geomorphological setting of the submarine canyon}

Tectonic activity significantly controls river patterns and behavior that have acted to shape the landscape we see today. For example, tectonic uplift strongly controls valley incision of the Tero River in central Portugal (Cunha et al., 2005). Geomorphologists have known for years that rivers are indicators of active tectonics (e.g., Howard, 1967). The link between tectonics and fluvial incision in the terrestrial terrains is also observed in the oceanic environments. For example, a fluvial-like meandering system in Wilmington Canyon occurs off the east coast of the United States (Stubblefield et al., 1982). The meander channel of Wilmington Canyon shows a microtopography similar to that of a fluvial channel. Canyon incision accelerated by ridge subduction is observed in the Tenryu Canyon off central Japan (Soh and Tokuyama, 2002). What makes investigation of a submarine canyon interesting is that submarine canyons are prominent topographic features on the sea floors of continental margins. Most deliver terrestrial sediment to the deep sea, but they also shape the present morphology of continental margins. Within a global context, similar tectonic control of canyon incision of sea floors may apply by analogy to that of a fluvial system in a terrestrial environment. Here, an attempt is made to introduce a marine morphotectonic study to be helpful for the geomorphologic research community worldwide.

Submarine canyons develop and form major physiographic features on the sea floors off the SW Taiwan margin. Five noticeable submarine canyons occur on the flat narrow shelf and a seaward dipping broad slope off SW Taiwan, namely the Shoushan, Kaohsiung, Kaoping, Fangliao and Hongtsai from the NW to the SE along the shoreline (Fig. 3). Among these canyons, the Kaoping Canyon is the largest with a length of about $260 \mathrm{~km}$, extending from its head immediately near the mouth of the Kaoping River, crossing the shelf and slope region, and finally merging into the northern end of the Manila Trench (Liu et al., 1993; Yu, 2003).

Canyon incision results from combined processes of erosion, axial incision, structural uplift, and tectonic subsidence of the slope region where most submarine canyons are distributed. In an active slope region, the canyon incision is strongly controlled by regional uplift and subsidence in addition to downward cutting of the underlying strata. For example, the canyon incision of the Tenryu Canyon is closely related to tectonic activities of the Tokai accretionary prism, Japan (Soh and Tokuyama, 2002). A tectonic subsidence of $>800 \mathrm{~m}$ in the Nankai Trough floor results in southward tilting of 


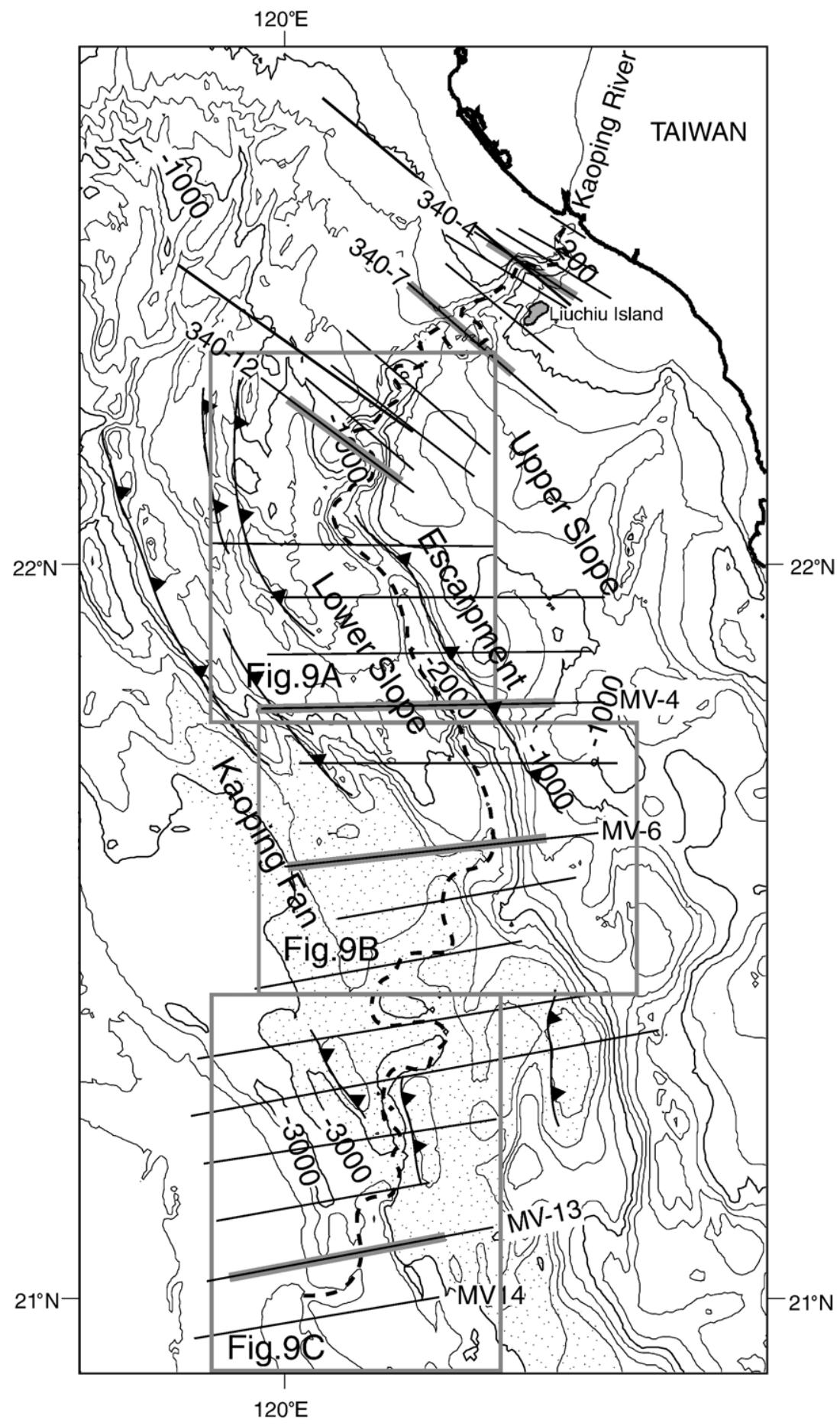

Fig. 2. Track lines of bathymetric profiles and multi-channel seismic reflection sections (bold face) in the offshore areas of the SW Taiwan. Thirteen profiles (340-1 through 340-13) across the upper reach of the Kaoping Canyon were acquired. Bathymetric profiles of MV-1 through MV-14 are retrieved from the data bank of the National Center for Ocean Research, National Taiwan University. The axis of the Kaoping Canyon is shown as broken lines.

the lower reach of the Tenryu Canyon, eroding the sea floor to adjust the topographic gap between the lower slope and the subsided Nankai Trough floor.
Most canyons are formed by downslope erosion of the sea floor on passive as well as active margins. The major difference is that tectonics controls the location 


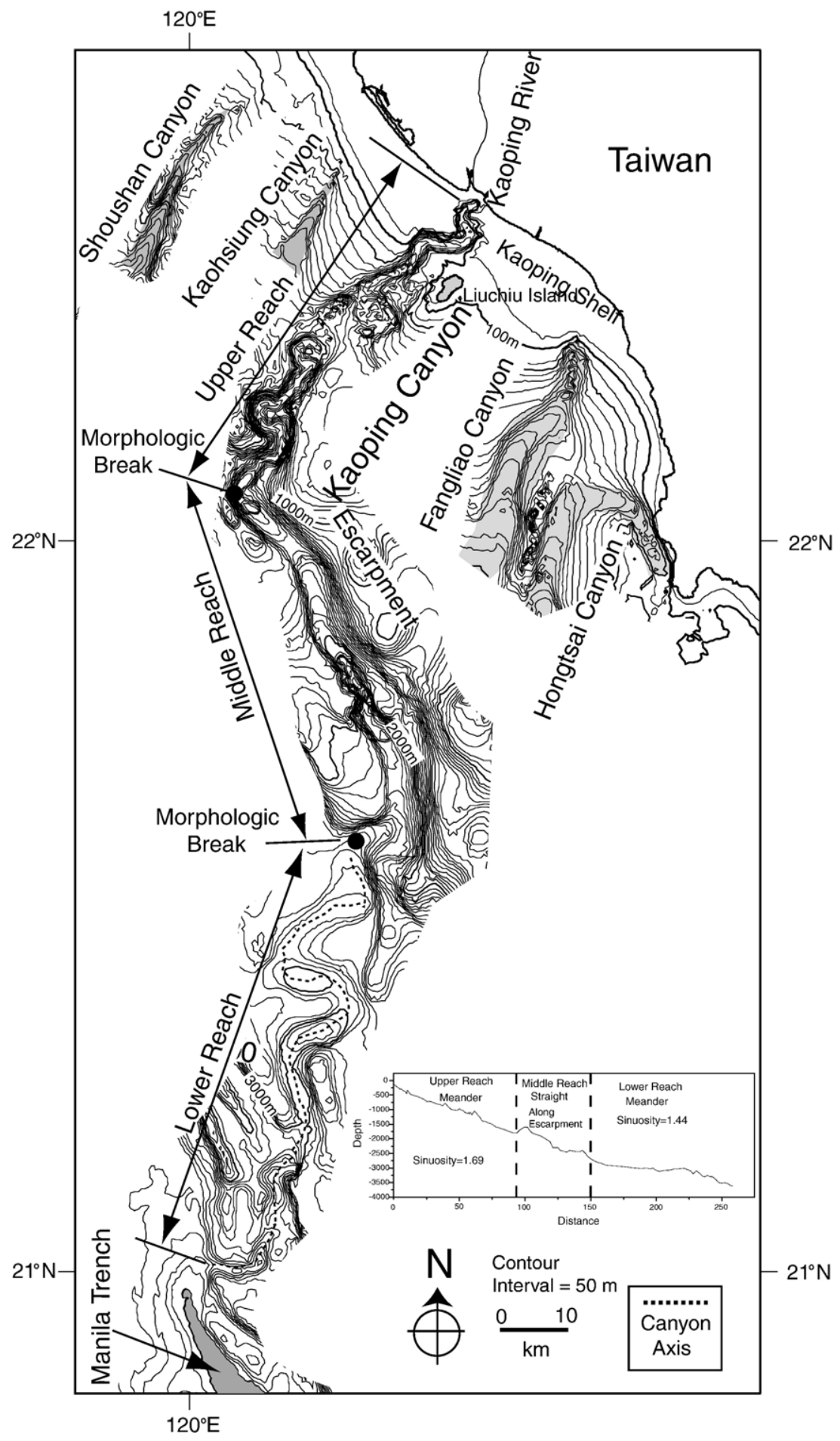

Fig. 3. The Kaoping Canyon consists of three distinct segments: an upper reach, a middle reach, and a lower reach. Note that there exist two distinct morphological breaks at the transitions of the reaches.

and orientation of a canyon while sedimentary processes contribute to the excavation and enlargement of a canyon. In active margins, for example, the course of the Monterey submarine canyon in southern California makes a sharp bend from WNW to SSW $(1800 \mathrm{~m})$, where it is crossed by the San Gregorio fault 
(Eittreim et al., 1989; Greene et al., 1989). Similarly, the San Antonio submarine canyon on the active margin of the Chile forearc shows that its course is deflected sharply to the north by a prominent structural high of a fault block (Hagen et al., 1996). In the present most seismically active margin of the NE Ionian Sea near Greece, the upper reach of the Kerkyra-Kefalonia submarine valley (canyon) trends NNW-SSE and bends sharply to the NE-SW along the lower reach, which is the morphotectonic expression of the Kefalonia strike-slip fault (Poulos et al., 1999). By analogy, the orientation of the Kaoping Canyon with two bends is closely controlled by tectonics and structures.

\subsection{Significance and purpose}

The Kaoping Canyon occurs in the active collision margin characterized by a narrow shelf and a broad slope, displaying an irregular and non-linear canyon course with two sharp bends (Figs. 1 and 4A). Judging from changing orientations of the canyon course, we suggest that the development of the Kaoping Canyon has been complicated mainly by intrusions of mud diapirs and westward thrust fauling, causing sharp bends of the canyon course and forming a prominent physiographic erosive feature with various cross-

\section{(A) Passive margin}

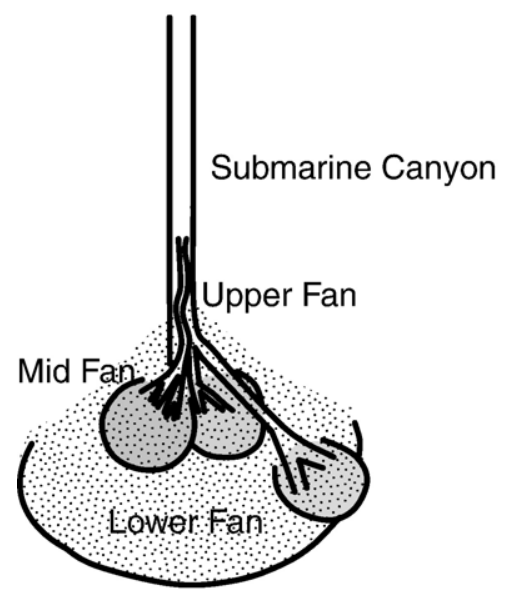

(after Walker, 1978) sectional forms. The Kaoping Canyon is an active sediment conduit between the rising Taiwan orogen and the deep sea Manila Trench. In contrast, canyons on passive margins cut wide shelves and erode the seabeds of the continental slopes transversely with a relatively straight canyon course. Submarine canyons stop eroding the continental slopes where a noticeable decrease in slope exists and the canyon mouth serves as a point sediment source, feeding sediment downslope and forming deep-sea fans (Fig. 4B). We consider the Kaoping Canyon as a variant of the canyon model of active margins. Information on the Kaoping Canyon may contribute to building a general active margin canyon model.

The morphology of the head portion of the Kaoping Canyon has been described by Yu et al. (1991, 1993). The general morphology of the Kaoping Canyon course was later described by Liu et al. (1993). We consider that investigations of canyon incision and related structural and sedimentary processes are needed to better understand the development of the Kaoping Canyon. This paper presents newly acquired bathymetric data and seismic reflection profiles to better characterize the morphological characteristics and to closely examine canyon incision and related tectonic and sedimentary processes in relation to the formation of the Kaoping Canyon.
(B) Active margin

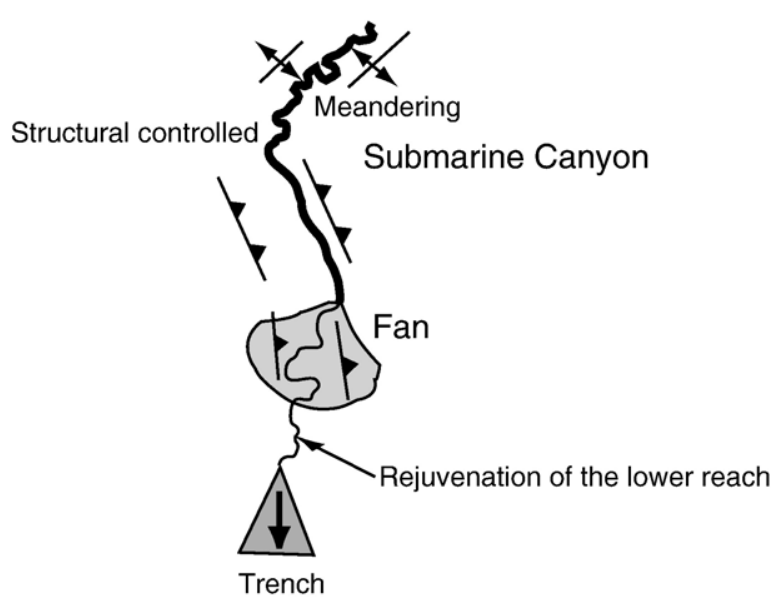

(this paper)

Fig. 4. Typical physiographic expression of a canyon-fan system is mainly caused by downslope erosion and deposition in passive margins (A) (Walker, 1978). Canyon morphology is mainly controlled by regional tectonics and local structural deformation, causing sharp bends in the canyon course and forming a prominent physiographic feature in active margins (this paper). Note that intrusions of mud diapirs and thrust faulting are associated with the canyon course. 


\section{Data}

Bathymetric data and seismic reflection profiles were collected in the upper reach of the Kaoping Canyon off southwestern Taiwan using the $R / V$ Ocean Researcher I, National Taiwan University (Fig. 2). Bathymetric data were collected by a Simrad EK 500 Sonar. Thirteen profiles across the axis of the upper reach of the Kaoping Canyon were made. Seismic profiles are oriented perpendicular to the course of the canyon. Newly acquired bathymetric data were integrated into the bathymetric databank at the National Center for Ocean Research, National Taiwan University. Bathymetric data were then grid and contoured using a GMT (Generic Mapping Tools) system (Wessel and Smith, 1991) to generate bathymetric charts covering the Kaoping Canyon. Bathymetric profiles of MV-1 through MV-14 (Liu et al., 1993) across the middle and lower reaches of the canyon are retrieved from the bathymetric databank. The website of the databank of NCOR is http://duck2.oc.ntu.edu.tw. The seismic energy was an airgun array, and seismic signals were recorded on a 300-m long, 4-channnel streamer with a DFS-V floating gain digital system. Seismic reflection data were processed using the SIOSEIS system and PROMAX software. Recorded marine seismic data were processed as follows: spectral analysis, automatic gain control, band-pass filter, velocity analysis, stack, frequencywavenumber analysis and migration.

\section{Geomorphology}

The Kaoping Canyon consists of three distinct segments: an upper reach, a middle reach, and a lower reach (Fig. 3). The upper reach begins at the Kaoping River mouth, extends meanderingly toward the SW on the upper slope area for a distance of about $88 \mathrm{~km}$ to a location of about $22^{\circ} \mathrm{N}$. and $120^{\circ} \mathrm{E}$., and is in water depth of about $1600 \mathrm{~m}$ where the canyon turns sharply to the southeast. The middle reach runs almost straight southeastward along an elongate escarpment for a distance of about $65 \mathrm{~km}$ and ends at about $21^{\circ} 40^{\prime} \mathrm{N}$. and $120^{\circ} 20^{\prime} \mathrm{E}$., and is in water depth of about $2600 \mathrm{~m}$ where the canyon course turns sharply to the SW. The lower reach stretches sinuously southwestward on the lower slope for a distance of about $100 \mathrm{~km}$ and finally merges into the northern Manila Trench at a water depth of about $3500 \mathrm{~m}$.

\subsection{Cross-sectional morphology}

Canyon morphology in cross-sectional view is presented in Fig. 5. The canyon head in front of the
Kaoping River mouth is shown as a relatively small Vshaped trough (profile 340-1). The canyon is about $2.8 \mathrm{~km}$ wide, and its bottom is about $186 \mathrm{~m}$ in water depth. South of the head, the cross-sectional areas increase and the cross-sectional morphology becomes a U-shaped trough (profiles 340-2 through 340-5). Farther downcanyon, the canyon meanders on the upper slope and the cross-sectional areas increase significantly (profiles 340-6 through 340-13). The canyon width increases greatly to about $9 \mathrm{~km}$, and its bottom reaches to about $1662 \mathrm{~m}$ in water depth. The cross-sectional morphology maintains a trough-like shape without a definite V or U shape. Note that the canyon shape is not symmetrical, with the east canyon wall being higher than the west canyon wall. Some canyon bottoms are irregular with small bulges in the middle (profiles 3408 through 340-11). Near the end of the upper reach, the canyon becomes a relatively large V-shaped trough and both walls have irregular surfaces (profiles 340-12 and 340-13).

The cross-sectional morphology of the middle reach of the Kaoping Canyon is revealed by profiles MV-1 through MV-6 and is characterized by an asymmetrical V-shaped trough with higher inclined east walls along the middle reach (Fig. 5). The canyon shape changes drastically from a V-shaped trough (MV-5) to a hardly recognizable shallow depression (MV-6) where the Kaoping Canyon makes a sharp bend toward the west at its southern end. The depth of canyon bottom increases from $1910 \mathrm{~m}$ (MV-1) to about $2766 \mathrm{~m}$ in water depth (MV-6). Farther downcanyon, profiles MV-7 through MV-14 show that the cross-sectional morphology along the lower reach of the Kaoping Canyon changes variably. Near the beginning of the lower reach, profile MV-7 shows that the canyon is a relatively broad and shallow trough without typical canyon morphology. Farther downcanyon, the morphology becomes an asymmetrical V-shaped trough with varying width and relief between the canyon bottom and edges. Note that the height of canyon edges is much higher than the surrounding sea floor, as shown on profiles MV-10 and MV-11. The apparent canyon width is about $7 \mathrm{~km}$. The canyon bottom reaches a water depth of about $3670 \mathrm{~m}$ (MV-14) before merging into the Manila Trench.

The cross-sectional morphology along the Kaoping Canyon changes considerably, ranging from U-shaped, broad V-shaped, to irregular troughs. The upper reach shows low relief and U-shaped cross sections with increasing size of the canyon downslope. The upper reach runs meanderingly downslope. The middle reach is characterized by an asymmetrical V-shaped trough 


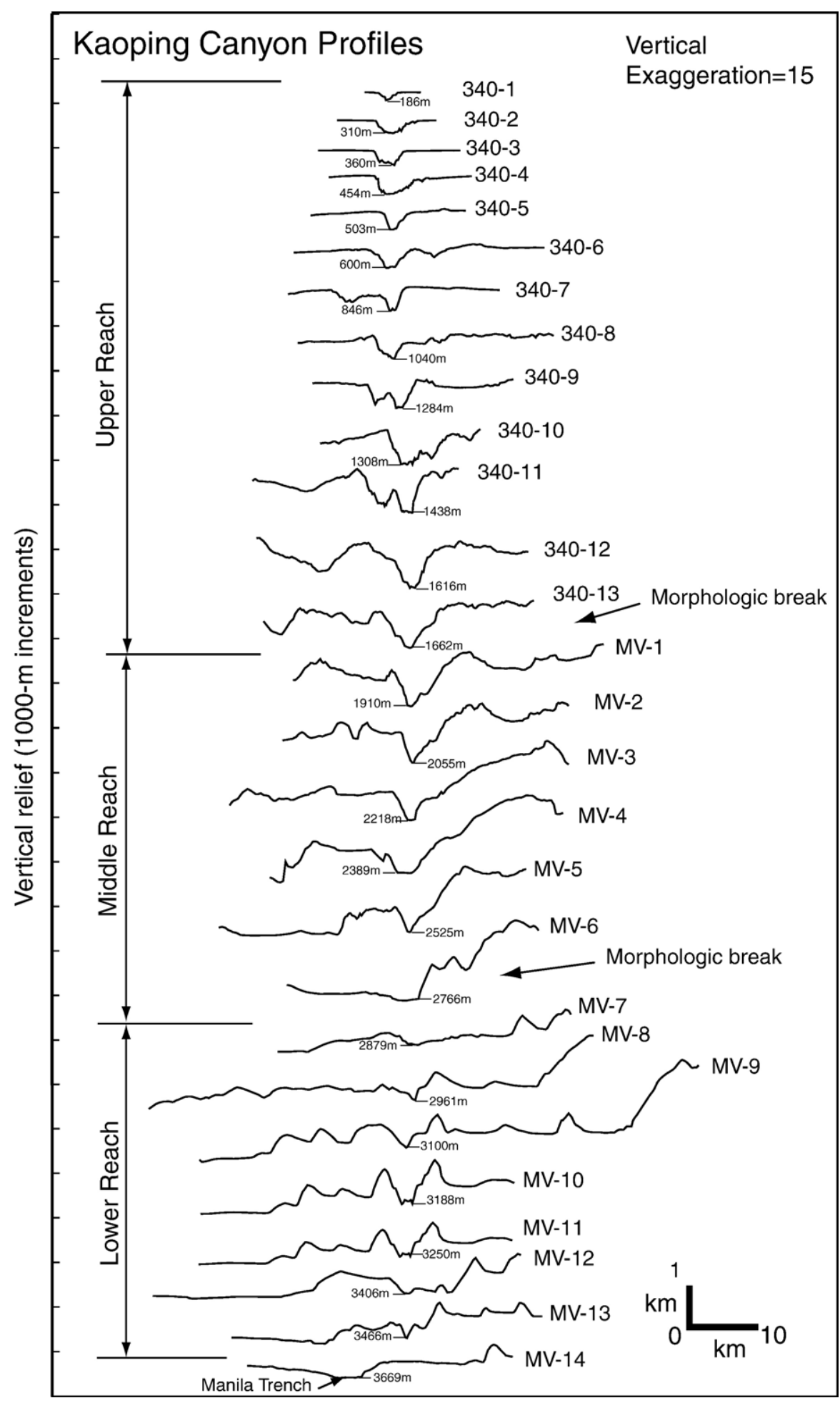

Fig. 5. Cross-sectional morphology of the Kaoping Canyon revealed by bathymetric transects. Locations of bathymetric profiles are shown in Fig. 2.

with a higher inclined east wall and aligned with tectonic lineaments. The lower reach is characterized by high relief, irregular troughs with canyon edges much higher than the surrounding sea floor. Meandering of the lower reach is related to the regional base level and structural highs. Overall, the canyon bottom increases in 
Table 1

Morphometric statistics along the track lines

\begin{tabular}{lrccll}
\hline $\begin{array}{l}\text { Track } \\
\text { lines }\end{array}$ & \multicolumn{1}{l}{$\begin{array}{l}\text { Width } \\
(\mathrm{m})\end{array}$} & $\begin{array}{l}\text { Relief } \\
(\mathrm{m})\end{array}$ & $\begin{array}{l}\text { Width/ } \\
\text { relief }\end{array}$ & $\begin{array}{l}\text { Structural } \\
\text { types }\end{array}$ & Orientation \\
\hline $340-1$ & 3317.29 & 161.3 & 20.57 & 1 & 1 \\
$340-2$ & 6871.53 & 258.1 & 26.62 & 1 & 1 \\
$340-3$ & 5449.83 & 322.6 & 16.89 & 1 & 1 \\
$340-4$ & 8293.22 & 387.1 & 21.42 & 1 & 1 \\
$340-5$ & 7108.47 & 387.1 & 18.36 & 1 & 1 \\
$340-6$ & 7819.32 & 419.4 & 18.64 & 1 & 1 \\
$340-7$ & $11,847.46$ & 483.9 & 24.48 & 1 & 1 \\
$340-8$ & 9477.97 & 467.7 & 20.27 & 1 & 1 \\
$340-9$ & 7819.32 & 548.4 & 14.26 & 1 & 1 \\
$340-10$ & $10,425.76$ & 709.7 & 14.69 & 1 & 1 \\
$340-11$ & $11,847.46$ & 935.5 & 12.66 & 1 & 1 \\
$340-12$ & $14,690.85$ & 1000 & 14.69 & 1 & 1 \\
$340-13$ & 9477.98 & 806.5 & 11.75 & 1 & 1 \\
MW-1 & 8293.22 & 806.5 & 10.28 & 2 & 2 \\
MW-2 & 5923.73 & 645.2 & 9.18 & 2 & 2 \\
MW-3 & 8293.22 & 645.2 & 12.85 & 2 & 2 \\
MW-4 & 6871.53 & 419.4 & 16.38 & 2 & 2 \\
MW-5 & 6397.63 & 548.4 & 11.67 & 2 & 2
\end{tabular}

Structural types: $1=$ mud diapir; $2=$ thrust fault.

Canyon and structure orientation: $1=\mathrm{NE} ; 2=\mathrm{NW}$.

depth from $186 \mathrm{~m}$ at the head to about $3670 \mathrm{~m}$ at its mouth, where it merges into the Manila Trench. The canyon width ranges from 2.8 to about $10 \mathrm{~km}$.

\subsection{Morphometric statistics analysis}

The morphology of three segments of the Kaoping canyon are considered to be related to structural and sedimentary processes. Three morphometric parameters of width, relief and the ratio of width to relief are considered to be linked to structures of the upper and middle reaches of the canyon. The width of the Kaoping canyon results mainly from sedimentary processes of sliding and slumping from both canyon walls. The relief of the canyon is mainly formed by axial incision and subsequent canyon wall collapse. Table 1 summarizes values of these three morphometric parameters obtained from eighteen bathymetric profiles. The Kaoping Canyon was classified into two structure types according to structural influence on surroundings of the canyon. A hypothesis of no difference in morphometry among structure types is rejected from the results of Independent-Sample $t$-test (Table 2). Levene's Test is summarized in the $F$ Ration shown $(F=1.793)$ and the corresponding Significant Probability $(p=0.199)$. Therefore, we assume Equal Variance for width/relief and structure types. The relevant $\mathrm{t}$ statistic is 2.759 with $P=0.014$ which is very highly significant. Variation in morphometry from high width/relief ratio (upper reach) to low width/relief ratio (middle reach) corresponds to a change in dominant structure from mud diapiric intrusions to thrust faulting. We conclude that there is indeed a significant difference between morphometry and structure types. The morphology of the upper reach is strongly influenced by intrusions of mud diapirs and morphometry of the middle reach is closely controlled by westward thrust faulting.

\section{Sedimentary and tectonic controls}

Using seismic profiles and bathymetric charts we relate variations and characteristics of canyon morphology (including the cross section views, location, orientation, and size) to structures of the frontal oregenic wedge off SW Taiwan and to the processes forming the Kaoping Canyon.

\subsection{Upper reach}

Seismic profile 340-4 (Fig. 6) shows that truncations of parallel reflectors against the west wall, indicating down-cutting of the canyon. Stepped and curved surfaces on the east wall indicate that sliding or

Table 2

Result of Independent Sample $t$-test of morphometric parameters (width/relief ratio) among structure types

\begin{tabular}{|c|c|c|c|c|c|c|c|c|c|c|}
\hline & & \multicolumn{2}{|c|}{$\begin{array}{l}\text { Levene's Test } \\
\text { for Equality of } \\
\text { Variances } \\
\end{array}$} & \multicolumn{7}{|c|}{$t$-test for Equality of Means } \\
\hline & & \multirow[t]{2}{*}{$F$} & \multirow[t]{2}{*}{ Sig. } & \multirow[t]{2}{*}{$t$} & \multirow[t]{2}{*}{$d f$} & \multirow[t]{2}{*}{$\begin{array}{l}\text { Sig. } \\
\text { (2-tailed) }\end{array}$} & \multirow[t]{2}{*}{$\begin{array}{l}\text { Mean } \\
\text { Difference }\end{array}$} & \multirow[t]{2}{*}{$\begin{array}{l}\text { Std. Error } \\
\text { Difference }\end{array}$} & \multicolumn{2}{|c|}{$\begin{array}{l}95 \% \text { Confidence } \\
\text { Interval of the } \\
\text { Difference }\end{array}$} \\
\hline & & & & & & & & & Lower & Upper \\
\hline \multirow[t]{2}{*}{ Ratio } & Equal variances assumed & 1.793 & 0.199 & 2.759 & 16 & 0.014 & 6.02781 & 2.18488 & 1.39609 & 10.65954 \\
\hline & Equal variances not assumed & & & 3.415 & 12.090 & 0.005 & 6.02781 & 1.76527 & 2.18479 & 9.87083 \\
\hline
\end{tabular}

This table gives the results of the two-tailed independent-Sample $t$-test of the morphometric parameters (width/relief ratio) is significantly $(p<0.05)$ among the structure types. 


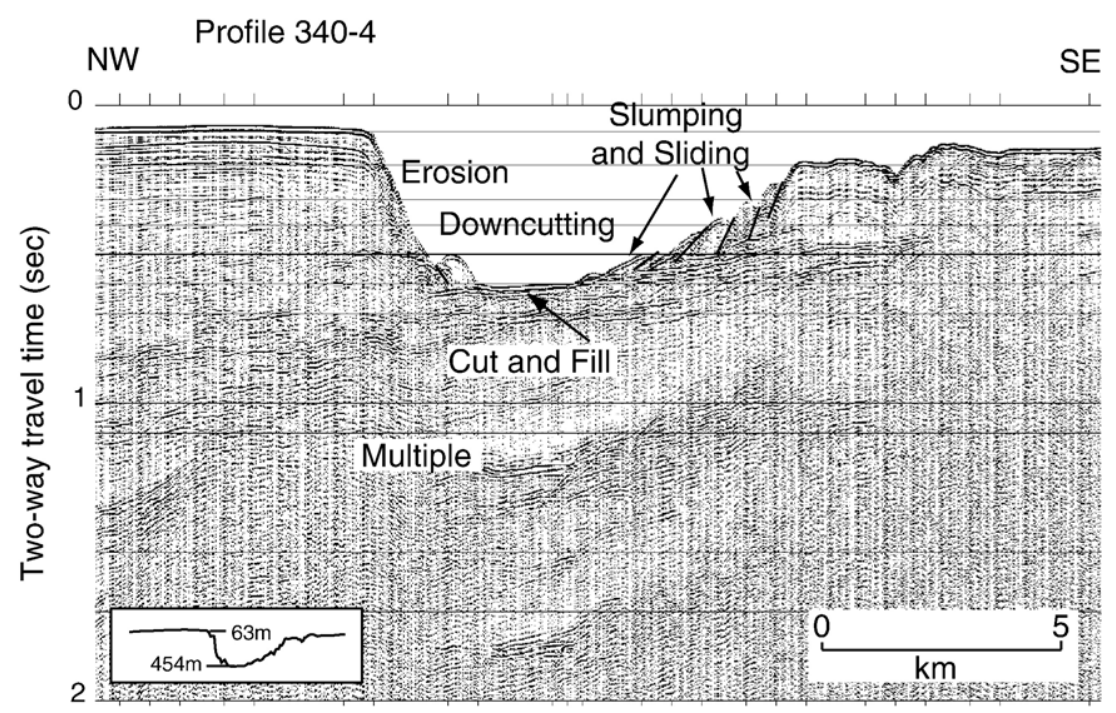

Fig. 6. Seismic profile 340-4 shows truncations of parallel reflectors against the west wall, indicating down-cutting of the canyon. Stepped and curved surfaces on the east wall indicate that sliding or slumping of the strata in the upper reach areas may have resulted in widening of the canyon. Downward excavation of canyon floors and slumping and sliding on the canyon walls are main processes for forming the head segment of canyon. The flat reflector at the canyon bottom is considered to be a cut-and-fill feature.

slumping of the strata in the upper reach areas may have resulted in widening the canyon to a maximum width of $8.3 \mathrm{~km}$. Slumped sediments of the east canyon wall are characterized by chaotic facies, which suggested that downward excavation of canyon floors and slumping and sliding on the canyon walls formed the head segment of the canyon. The maximum incision of the seabed by this segment of the Kaoping Canyon reaches to $387 \mathrm{~m}$, as determined by relief between canyon bottom and edges. The flat reflector at the canyon bottom is considered to be a cut-and-fill feature. Sediments transported from eroded canyon walls nearby or from up-canyon have been deposited and have partially filled the canyon bottom, resulting in a flat surface. During canyon development, multiple canyon cut-and-fill features are common (McGregor, 1981; Twichell and Roberts, 1982). Liu et al. (1993) recognized multiple cut-and-fill events occurring in the middle and lower segments of the Kaoping Canyon. Farther downcanyon, the course of the canyon runs sinuously to form a meandering canyon for the rest of the upper reach (Fig. 2). Seismic profile 340-7 (Fig. 7) across the major meander loop SW of Liuchiu Island, a mud diapiric intrusion above the seabed, shows that truncations of parallel reflectors against the east wall indicate down-cutting of the canyon. The process of excavation takes place mainly along the outer bend of a meander, i.e., the east wall. Subsequently, a narrow canyon thalweg resulting from the down-cutting is formed along the east wall. On the other hand, the west wall of the canyon, i.e., the inner bend, is characterized by slumping or sliding features. A relatively shallow abandoned channel is located at the bottom of the west wall. The width of the canyon thalweg is about $2 \mathrm{~km}$, much less than the apparent width of about $10 \mathrm{~km}$ of the whole canyon. Canyon incision of this segment of the upper reach ranges from 500 to about $960 \mathrm{~m}$, which is greater than that of the head segment. The increases of width and incision of the canyon imply greater intensity of erosion of down-cutting of the canyon floor and slumping and sliding on the walls to widen the canyon.

However, the irregular cross-sectional forms of the canyon do not show typical V-shaped or U-shaped canyon morphology, implying structural complications. Seismic profile 340-12 shows down-cutting of the canyon into mud diapir instead of layered slope strata (Fig. 8). Stepped and curved surfaces on the west wall can be a result of slumping or sliding. Alternatively, the present canyon form could be a feature of valley-invalley, resulting from a combination of downward incision and upward intrusion of mud diapirs. We inferred that the segment marked as $\mathrm{C}$ on the west wall resulted from axial down-cutting at the earliest stage. Subsequently, continued upward intrusion and axial down-cutting have resulted in the segment marked as B on the west wall. Finally, the axial down-cutting of the mud diapirs forms the A segment on the west wall. This simplified explanation may account for the apparent canyon width of about $13 \mathrm{~km}$ and the apparent canyon incision of about $960 \mathrm{~m}$ in relief, resulting from a 


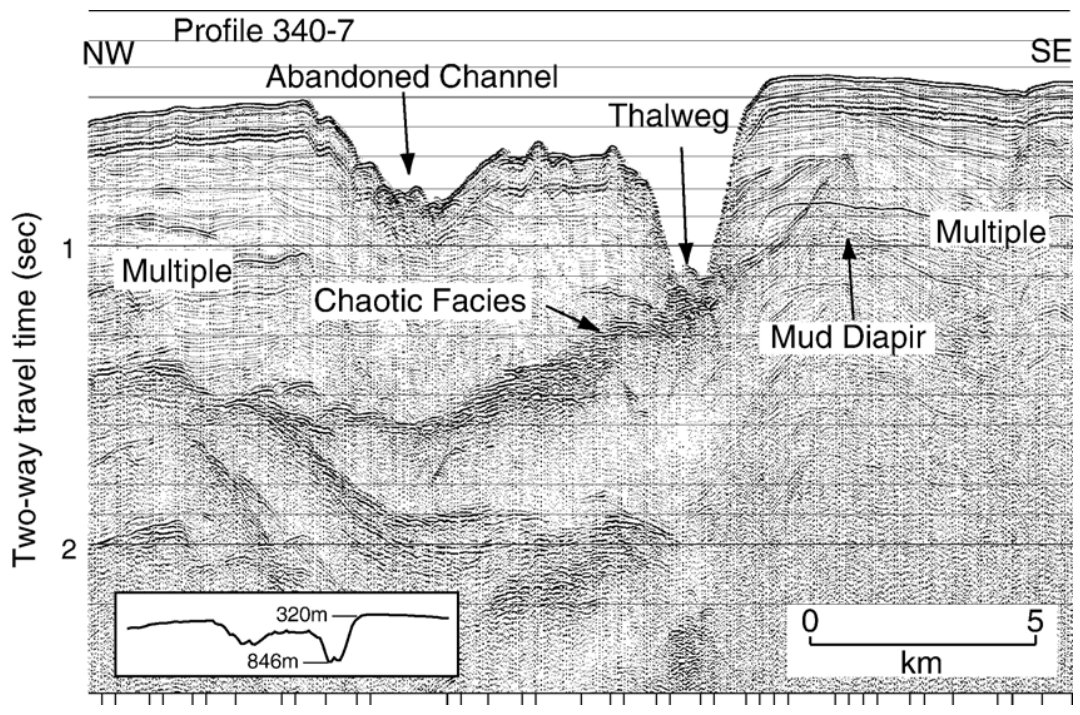

Fig. 7. Seismic profile 340-7 across the major meander SW of Liuchiu Island shows truncations of parallel reflectors against the east wall, indicating down-cutting of the canyon. Excavation takes place mainly along the outer bend of a meander, i.e. the east wall. A narrow V-shaped canyon thalweg resulting from the down-cutting is formed immediately along the bottom of the east wall. The west wall of the canyon, i.e., the inner bend, is characterized by slumping or sliding features. A relatively shallow abandoned channel is located at the bottom of the west wall.

combination of sequential upward intrusion of mud diapirs and axial down-cutting. Seismic characteristics of these four seismic sections from the head to the end of the upper reach suggest that downward excavation into the layered slope sediments and slumping or sliding on the canyon walls are the major sedimentary processes in the canyon head segment. Seabed has been moved upward by mud diapiric intrusions and has become important of incision in the lower segment of the upper reach of the Kaoping Canyon.

The bathymetric map (Fig. 9A) shows that near the end of the upper reach of the Kaoping Canyon the ridge marked as " $\mathrm{X}$ " blocks the southwestward flow of the canyon and forces the course to turn sharply to the east. The canyon course then is confined by the northern end of the escarpment to the east and another

\section{Profile 340-12}

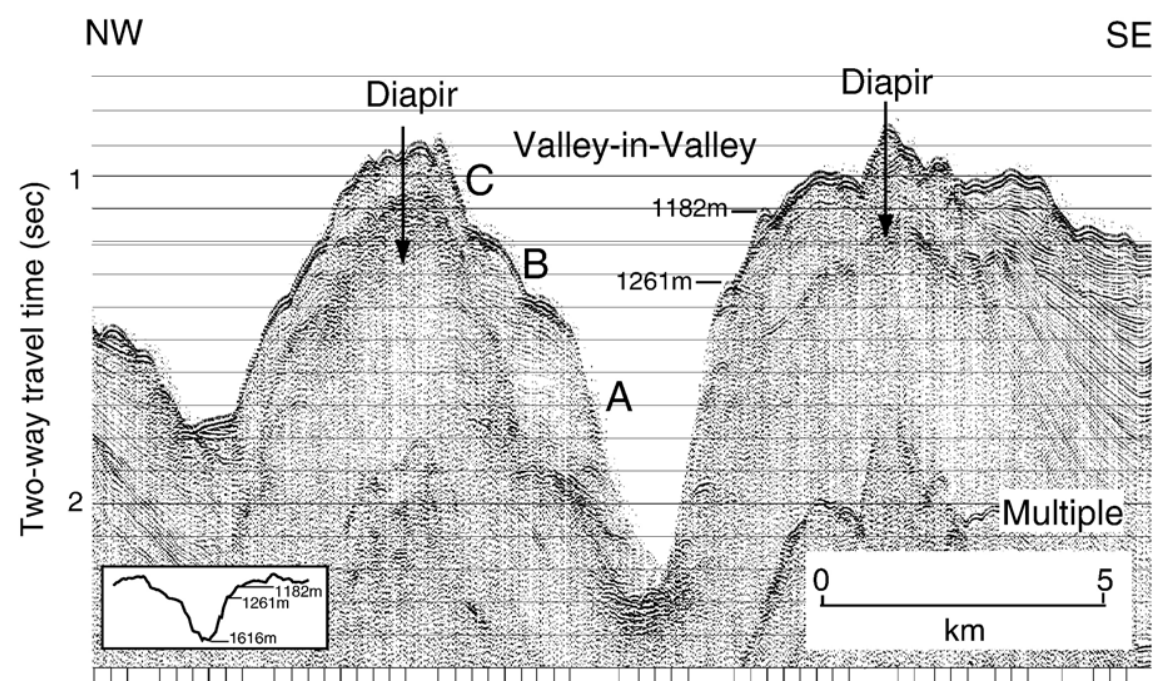

Fig. 8. Seismic profile indicates that the excavation of canyon downward into mud diapiric intrusions penetrate upward and through the overlying slope sediments and rise above the sea floor to form relatively great ridges. Diapiric intrusions become important in the formation of the down-canyon segment of the upper reach of the Kaoping Canyon. 
ridge to the west and then is forced to turn sharply to the southeast and run continuously along the sea valley between two elongate ridges. Seismic charac-

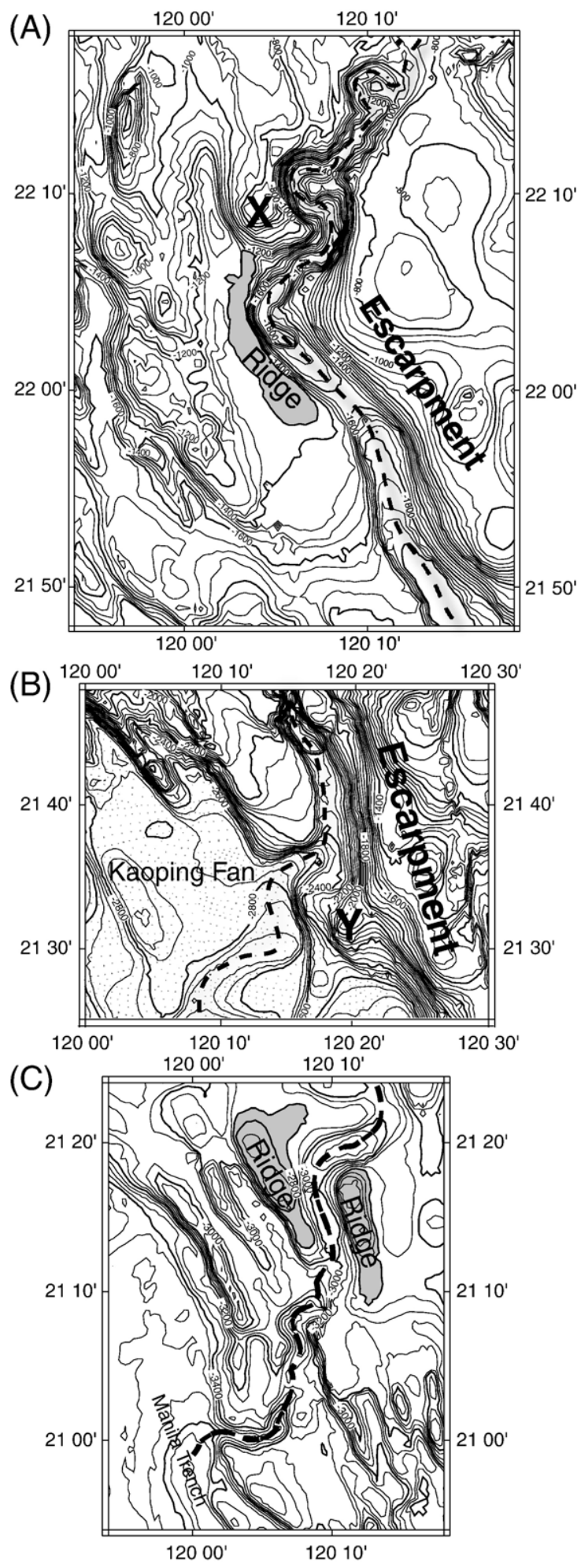

teristics and bathymetric configurations together suggest that canyon incision and meandering in the head segment are mainly influenced by regional base level, but incision and meandering of the canyon at the downcanyon segment of the upper reach are complicated by mud diapiric intrusions.

\subsection{Middle reach}

The west-vergent thrust faults between two major bends of the middle reach of the Kaoping Canyon form a prominent linear escarpment over $1500 \mathrm{~m}$ above the surrounding sea floor as shown in Figs. 3 and 4 (Reed et al., 1992). A thrust fault zone existing parallel to and west of this linear escarpment was recognized by Liu et al. (1993). Seismic profile MV-4 shows that surface expression of the linear fault zone is a moderately uplifted lineament up to about $700 \mathrm{~m}$ above the canyon bottom (Fig. 10A). We suggest that an eastward-tilted piggy-back basin develops between these two fault zones, indicating the structural effect on the formation of a slope basin on the Kaoping Slope. The Kaoping Canyon excavates the basin bottom located along the foot of the escarpment to the east. Seismic profile A shows that the piggy-back basin is bounded to the west by the thrust fault, a bathymetric high, and by the inclined slope of the escarpment to the east (Fig. 10A). The basin fills are about $600 \mathrm{~m}$ thick and are represented as parallel reflections slightly dipping to the east. The Kaoping Canyon runs from north to south downslope along the foot of the escarpment where sediments in the lowest part of the basin are removed, resulting in a Ushaped canyon thalweg with an incision depth of about $550 \mathrm{~m}$ and a width of about $5.3 \mathrm{~km}$. Seismic profile MV6 lies farther downcanyon across the southern end of the middle reach (Fig. 10B), showing that the piggy-back basin (bounded by two thrust faults) are similar to that shown in seismic profile MV-4 and that this basin is the southern end of the elongate piggy-back basin west of the escarpment. Note that the U-shaped canyon thalweg

Fig. 9. Bathymetric map showing that near the end of the upper reach the southwestward canyon course is blocked by the ridge marked as " $\mathrm{X}$ ". The canyon course is forced to turn sharply to the east and then is blocked by the northern part of the prominent escarpment. The canyon turns sharply to the south and then meanders sinuously along the sea valley between two ridges (A). Near the termination of the middle reach, the canyon course is blocked by the structural high marked by "Y" and is deflected to the west. The suggested small Kaoping Fan has been supplied with sediment from the middle reach termination (B). The canyon course of the lower reach is strongly controlled by the linear ridges $(\mathrm{C})$. 


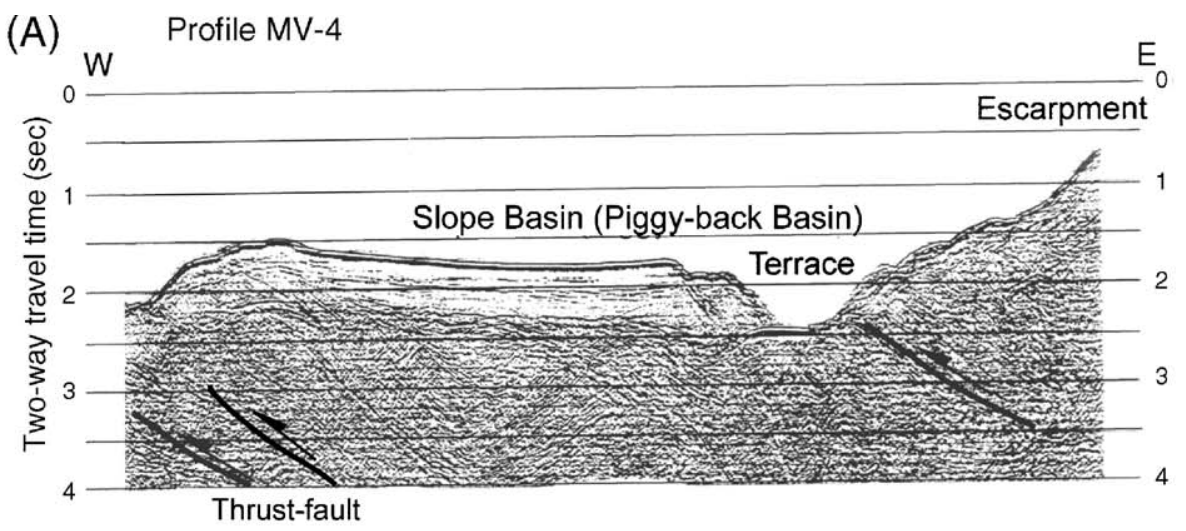

(B) Profile MV-6
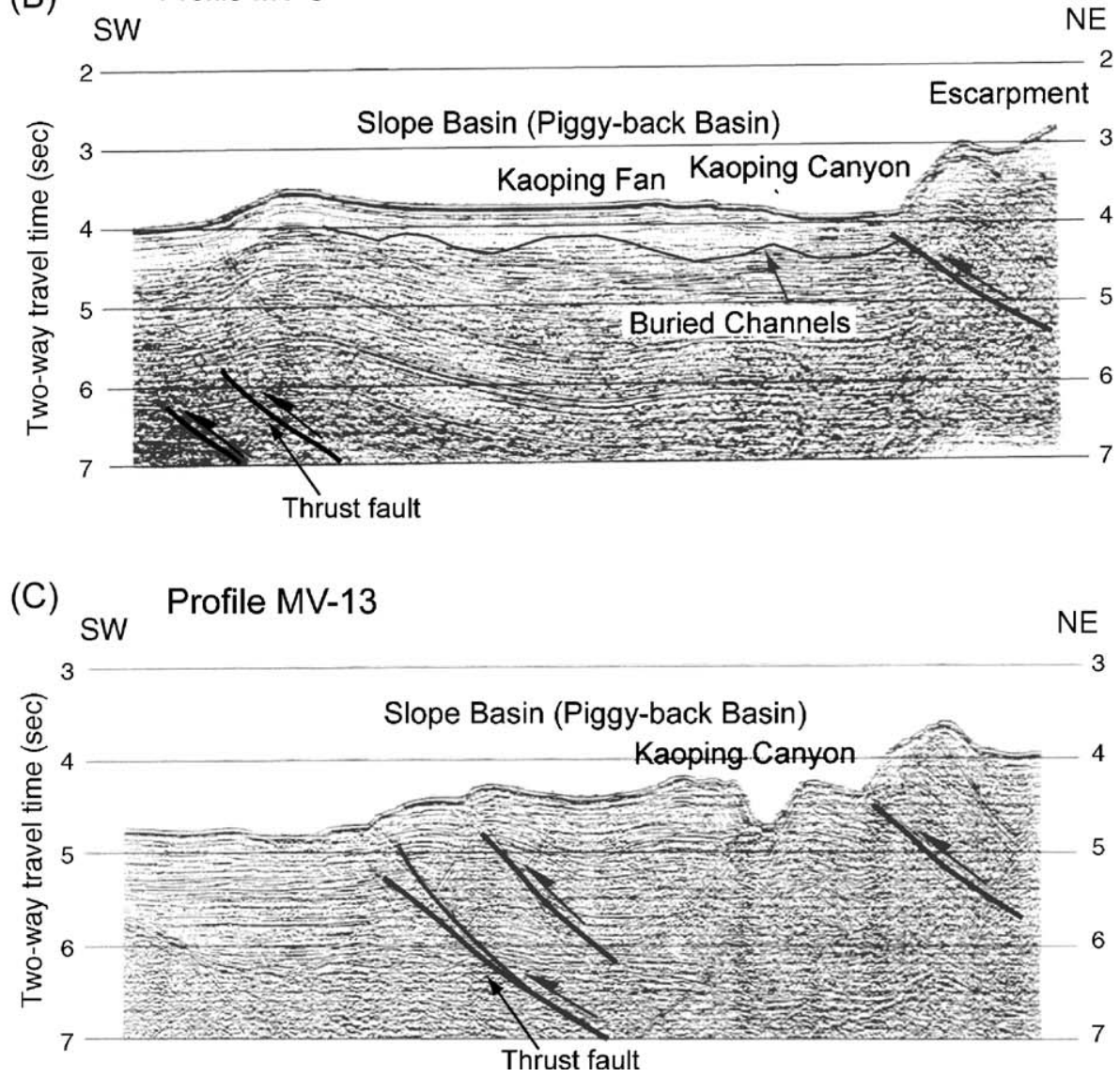

Fig. 10. Seismic profile MV-4 shows that the piggy-back basin is bounded to the west by the thrust fault, a bathymetric high, and by the inclined slope of the escarpment to the east. The Kaoping Canyon runs from north to south downslope along the foot of the escarpment where sediments in the lowest part of the basin are removed, resulting in a U-shaped canyon thalweg (A). Characteristics of seismic profile MV-6 are similar to that of seismic profile MV-4, except for the absence of a U-shaped canyon thalweg (B). Seismic profile MV-13 shows that canyon incision results in a relatively small-sized V-shaped thalweg with a width of about $1.8 \mathrm{~km}$ and an incision of about $330 \mathrm{~m}$ (C). (Modified from Liu et al., 1993.)

with considerable incision at the foot of the escarpment cannot be recognized from seismic profile MV-6, implying reduced intensity of erosion of the basin fills by axial incision.

\subsection{Lower reach}

Bathymetric profiles MV-10 and MV-11 show the cross-sectional morphology characteristics of large V- 
shaped troughs with an apparent incision $>900 \mathrm{~m}$ (Fig. 5 ). Note that canyon edges are much higher than the surrounding sea floor, implying apparent incision from structural uplift rather than erosion of down-cutting. The bathymetric map in the lower reach areas indicates that the canyon course crossed by profiles MV-10 and 11 is confined by a nearly north-south trending sea valley between two ridges. These two ridges resulted from uplifting of slope sediment by thrusting and folding (Liu et al., 1997; Chiang et al., 2004). Therefore, the apparent canyon incision and morphology are mainly from structural uplifting. In other words, structural effect overprints the effect of erosion.

The structure-controlled ridges not only produce apparent cross-sectional morphology but also cause the canyon course to meander. The bathymetric map (Fig. 9B) shows that the canyon course runs southwestward following the regional depositional slope until it meet a ridge to the west. Then the canyon course makes a sharp bend to the south and flows along the sea valley between two ridges (Fig. 9C). Seismic profile MV-13 (Fig. 10C) shows that sediments of the Kaoping lower slope are compressed by the westward thrusting and uplifted to form a prototype piggy-back basin east of the Manila Trench. The concept of stream rejuvenation is applied to interpret the morphology of the lower reach. Tectonic uplift of seabed surface in the lower reach area causes an increase in gradient, resulting in renewed energy for canyon down-cutting. The uplifting of deformed slope sediments raises the slope gradient along the canyon bottom and consequently induces canyon incision of slope sediments, leading to an equilibrium profile of the lower reach of the Kaoping Canyon. The small inset map on Fig. 4 shows the long profile of the lower reach convex upward and this may be suggestive of active tectonics of regional tilting southward in the lower reach area. Note that the rejuvenation of canyon incision results in a relatively small-sized canyon with a width of about $1.8 \mathrm{~km}$ and a canyon incision depth of about $330 \mathrm{~m}$. The intensity of incision is similar to that in the head segment of the Kaoping Canyon. The rest of the lower reach continues to run sinuously southwestward on the Kaoping lower slope and ends at the Manila Trench.

\section{Summary and conclusions}

We used seismic reflection profiles and examined detailed bathymetric data to reveal the characteristic morphology and related tectonics of the Kaoping Canyon in an active margin off SW Taiwan. The Kaoping Canyon is characterized by prominent mor- phological breaks along its entire course of $\sim 260 \mathrm{~km}$ with two sharp bends, resulting in three distinct segments: an upper reach, a middle reach, and a lower reach. The upper reach extends meanderingly toward the SW on the upper slope area and characterized by low relief and U-shaped cross-sections. The middle reach runs almost straight southeastward along an elongate escarpment and has asymmetrical V-shaped crosssections. The lower reach stretches sinuously southwestward on the lower slope and is characterized by high relief irregular troughs with canyon edges being much higher than the surrounding sea floors. Morphometric statistics analysis and seismic interpretations indicated that the controlling structural features are intrusions of mud diapirs and thrust faulting for the regional canyon morphology.

Seismic characteristics suggest that downward excavation into the layered slope sediments and slumping or sliding on the canyon walls is the major sedimentary processes in the canyon head segment. Structural uplift associated with diapiric intrusions becomes important of incision in the lower segment of the upper reach of the Kaoping Canyon. The middle reach runs from northwest to southeast downslope along the foot of the escarpment where sediments in the lowest part of the piggy-back basin are excavated, resulting in a U-shaped canyon thalweg with considerable incision. Cut-and-fill features are commonly present. The orientation of the middle reach is strongly controlled by the tectonic lineaments. In the lower reach of the canyon, westward thrust faults uplifted lower slope sediments and raised the regional base level to tilt southwestward, causing incision of the slope sediments and formation of the canyon. The rejuvenation of canyon incision results in a relatively small-sized canyon similar to that in the head segment of the canyon. Incision and morphology of the Kaoping Canyon vary considerably and are related closely to tectono-sedimentary processes. The Kaoping Canyon may be served as a variant of canyon model of active margins with a distinct morphology of two sharp bends along the canyon course associated with structure deformation.

\section{Acknowledgements}

We wish to thank the captain and crew of the $R / V$ Ocean Researcher $I$ for collection of the marine data. Financial support comes from the National Science Council, Taiwan. Critical reviews from James Liu, National Sun-Yet-San University are greatly appreciated. Three anonymous reviewers gave very valuable comments and suggestions that greatly improved quality 
of our manuscript. Many thanks go to Dr. R.A. Marston for his encouragement and time-consuming editorial efforts.

\section{References}

Aisan, A., Guevara, E.H., Smyth, R.C., Rancy, J.A., Gibeau, J.C., Warne, A.G., White, W.A., 2001. Mud volcanoes of the Orinoco Delta, Eastern Venezuela. Geomorphology 41, 323-336.

Chang, C.H., 1993. Studies of mud diapirs offshore southwestern Taiwan. MS thesis. Institute of Oceanography, National Taiwan University, Taipei.

Chiang, C.S., Yu, H.S., Chou, Y.W., 2004. Characteristics of the wedge-top depozone of the southern Taiwan foreland basin system. Basin Res. 16, 65-78.

Chow, J., Lee, J.S., Liu, C.S., Lee, B.D., Watkins, J.S., 2001. A submarine canyon as the cause of a mud volcano-Liuchieuyu Island in Taiwan. Mar. Geol. 176, 55-63.

Covey, M., 1984. Lithofacies analysis and basin reconstruction, PlioPleistocene western Taiwan foredeep. Pet. Geol. Taiwan 20, 53-83.

Cunha, P.P., Martins, A.A., Daveau, S., Friend, P.F., 2005. Tectonic control of the Tejo River fluvial incision during the late Cenozoic, in Rodao-central Portugal (Atlantic Iberian border). Geomorphology 64, 271-298.

Eittreim, S.L., Embley, R.W., Normark, W.R., Greene, H.G., McHugh, C.M., Ryan, B.F., 1989. Observations in Monterey Canyon and Fan Valley using the Submersible ALVIN and Photographic Sled. USGS Open-File Rep. 89-291, Reston, VA.

Greene, H.G., Stubblefield, W.L., Thebergc, A.E., 1989. Geology of the Monterey submarine canyon system and adjacent areas, offshore central California. USGS Open-File Rep. 89-221. Reston, VA.

Hagen, R.A., Vergara, H., Naar, D.F., 1996. Morphology of San Antionio submarine canyon on the central Chile forearc. Mar. Geol. 129, 197-205.

Ho, C.S., 1988. An Introduction to the Geology of Taiwan: Explanatory Text of the Geologic Map of Taiwan. Central Geol. Surv., Minist. Eco. Affairs, Taipei.

Howard, A.D., 1967. Drainage analysis in geologic interpretation: a summary. Am. Assoc. Pet. Geol. 51, 2246-2259.

Hsieh, S.H., 1970. Geology and gravity anomalies of the Pingtung Plain, Taiwan. Proc. Geol. Soc. China 13, 76-89.

Lallemand, S.E., Tsien, H.H., 1997. An introduction to active collision in Taiwan. Tectonophysics 274, 1-4.

Limonov, A.F., Woodside, J.M., Cita, M.B., Ivanov, M.K., 1996. The Mediterranean Ridge and related mud diaprisim: a background. Mar. Geol. 132, 7-19.

Liu, C.S., Lundberg, N., Reed, D.L., Huang, Y.L., 1993. Morphological and seismic characteristics of the Kaoping Submarine Canyon. Mar. Geol. 111, 93-108.

Liu, C.S., Huang, Y.L., Teng, L.S., 1997. Structural features off southwestern Taiwan. Mar. Geol. 137, 305-319.

McGregor, B.A., 1981. Ancestral head of Wilmington Canyon. Geology 9, 254-257.

Milliman, J.D., Syvitski, J.P.M., 1992. Geomorphic/tectonic control of sediment discharge to the ocean: the importance of small mountainous rivers. J. Geol. 100, 525-544.

Poulos, S., Lykousis, V., Collins, M.B., Rohling, E.J., Pattiaratchi, C. B., 1999. Sedimentation processes in a tectonically active environment: the Kerkyra-Kefalonia submarine valley system (NE Ionian Sea). Mar. Geol. 160, 25-44.

Reed, D.L., Lundberg, N., Liu, C.S., Kuo, B.Y., 1992. Structural relations along the margins of the offshore Taiwan accretionary wedge: implications for accretion and crustal kinematics. Acta Geol. Taiwan. 30, 105-122.

Soh, W., Tokuyama, H., 2002. Rejuvenation of submarine canyon associated with ridge subduction, Tenryu Canyon, off Tokai, central Japan. Mar. Geol. 187, 203-220.

Stubblefield, W.L., McGregor, B.A., Forde, E.B., Lambert, D.N., Merrill, G.F., 1982. Reconnaissance in DSRV ALVIN of a fluviallike meander system in Wilmington Canyon, and slump features in South Wilmington Canyon. Geology 10, 31-36.

Sumner, R.H., Westbrook, G.K., 1977. Mud diapirism in the front of the Barbados accretionary wedge: the influence of fracture zones and North America-South America plate motions. Mar. Pet. Geol. 8, 591-613.

Sun, S.C., Liu, C.S., 1993. Mud diapirs and submarine channel deposits in offshore Kaohsiung-Hengchun, Southwest Taiwan. Pet. Geol. Taiwan 28, 1-14.

Suppe, J., 1981. Mechanics of mountain building and metamorphism in Taiwan. Geol. Soc. China Mem. 4, 67-89.

Suppe, J., 1987. The active Taiwan mountain belt. In: Schaer, J., Rogers, J. (Eds.), Comparative Anatomy of Mountain Ranges. Princeton Univ. Press, Princeton, NJ, pp. 277-293.

Twichell, D.C., Roberts, D.G., 1982. Morphology, distribution, and development of submarine canyons on the United States Atlantic continental slope between Hudson and Baltimore Canyons. Geology 10, 408-412.

Walker, R.G., 1978. Deep-water sandstone facies and ancient submarine fans: models for exploration for stratigraphic traps. Am. Assoc. Pet. Geol. 62 (6), 932-966.

Wessel, P., Smith, W.H.F., 1991. The GMT-System Version 2.0. Technical Reference and Cookbook, Scripps Inst. Oceanography, Univ. Calif., San Diego. 77 pp.

Westbrook, G.K., Smith, M.J., 1983. Long decollements and mud volcanoes: evidence from the Barbados Ridge Complex for the role of high pore-pressure in the development of an accretionary complex. Geology 11, 279-283.

Yassir, N., 2003. The role of shear stress in mobilizing deep-seated mud volcanoes: geological and geomechanical evidence from Trinida and Taiwan. GSA Spec. Publ. 216, 461-474.

Yu, H.S., 2003. Geological characteristics and distribution of submarine physiographic features in the Taiwan region. Mar. Georesour. Geotechnol. 21, 139-153.

Yu, H.S., Chiang, C.S., 1997. Kaoping Shelf: morphology and tectonic significance. J. Southeast Asian Earth Sci. 15, 9-18.

Yu, H.S., Chou, Y.W., 2001. Characteristics and development of the flexural forebulge and basal unconformity of Western Taiwan Foreland Basin. Tectonophysics 333, 277-291.

Yu, H.S., Lu, J.C., 1995. Development of the shale diapir-controlled Fangliao Canyon on the continental slope off southwestern Taiwan. J. Southeast Asian Earth Sci. 11 (4), 256-276.

Yu, H.S., Huang, C.S., Ku, J.W., 1991. Morphology and possible origin of the Kaoping Submarine Canyon head off southwest Taiwan. Acta Oceanogr. Taiwan. 26, 40-50.

Yu, H.S., Auster, P.J., Cooper, R.A., 1993. Surface geology and biology at the head of the Kaoping Canyon off southwestern Taiwan. Terr. Atmos. Ocean. Sci. 4, 441-455. 